\title{
Marrying, Loving, and Dreaming: A Case Study of the Developmental Tasks of Lasting Marriages in the Philippines
}

\author{
Jan Gresil S. Kahambing, SThB \\ Leyte Normal University, \\ Tacloban City, Leyte, Philippines \\ Jabin J. Deguma, RGC \\ Cebu Technological University, \\ Cebu City, Philippines \\ Melona C. Deguma, RGC \\ Cebu Technological University, \\ Cebu City, Philippines
}

Doi: 10.36941/ajis-2019-0021

\begin{abstract}
This paper is a case study of lasting marriages in the Philippines. It examines couples who are together or are still married for 25 years or more. This study evaluates three couples using Judith Wallerstein's and Sandra Blakeslee's Nine Developmental Tasks of Marriage. It will examine its effectiveness up to date while being open for recent tasks not mentioned. With the interdisciplinary component of theological studies coupled with guidance and counselling concerning the family, the study will also connect the analysis of these marriages in the idea of Marrying, Loving, and Dreaming, the third one being an important element in marriage as Pope Francis said in his meeting with families in the Philippines last January 2015. The analysis will try to weave the effectiveness of the Nine Tasks with some ideas of the new exhortation 'Amoris Laetitia' of the Holy Father but still following the trajectory of marrying, loving, and dreaming. This paper juxtaposes a secular study on marriages with a Catholic point of view when the element of being Christ-centered enters the scene. The theological assertion is that marriage, love, and dreaming would be nothing without God.
\end{abstract}

Keywords: Marriage, Love, Dreaming, Pope Francis, Tasks of Marriage, Family, Amoris Laetitia

\section{The State of the Question}

The idea of marriage passed painstakingly through the crucible of history. The element of time and this means all the other factors that underlie within such temporality - is not only a crucial element of an idea of marriage, but also the contingency of every passing moment. For the Christian who believes in marriage as a divine institution in the form of monogamy pattered on agape that is eternal, the test of time in marriage is a series of trying moments. Not only does the contingent air affect the marriage, but the spouses themselves are temporal beings only capable of entering into a glimpse of what real life is. The test of love becomes more crucial in the agency of persons who are facing death or are bound for the mortality they assumed, in which an inner longing for forever fuels the drama of existence's cruelty (Kahambing, 2015).

As early as the time of the Ancient Hellenes, the Greek philosopher Socrates once said a 
humorous statement that was referred to or as penned by Plato, or probably by a pseudo-Socrates, in the lines: "By all means, marry. If you get a good wife, you'll become happy; if you get a bad one, you'll become a philosopher." In this line of thought, perhaps the immediate scenario we can imagine are the married people who seem to have regretted the life situation that they dared enter into. Love as depicted in Asimov's film, for instance, is a matter of risking a choice (Kahambing \& Deguma, 2019). Such thought in the philosophy of the time of antiquity gives us a hint of the possible effect of goodness and its absence in the relationship of two persons who want to preserve a union. The question of happiness throughout the marriage union becomes an inquiry of decisions, most of the time regarding the sustenance of one's marriage and how it has come about for the present. The same question fuels the evaluation of our predicament in this paper: how the study of lasting marriages can inform us by evaluating their experiences and how they have worked things out, thereby extracting the goodness of marriage rather than being paralyzed by the situation itself.

In about the late $19^{\text {th }}$ Century, the German philosopher Friedrich Nietzsche stipulated: "When marrying, ask yourself this question: Do you believe that you will be able to converse well with this person into your old age? Everything else in marriage is transitory." In the same vein, he says, "It is not a lack of love, but a lack of friendship that makes unhappy marriages." Herein lies the most important element that has opened the postmodern enterprise until today. Although with a secular tone, Nietzsche pointed out the underlying kernel of marriage which makes it work and even blooms throughout the transitory auspices of time: that one opens oneself to what Nietzsche calls a noble "star friendship" that speaks about one's narrative and a continuing narrative:

\begin{abstract}
We are two ships, each of which has its own goal and course; we may cross and have a feast together, as we did - and then the good ships lay so quietly in one harbor and in one sun that it may have seemed as if they had already completed their course and had the same goal. But then the almighty force of our projects drove us apart once again, into different seas and sunny zones (Nietzsche, 2001, p. 159; cf. Nettleton, 2009)
\end{abstract}

Postmodernism's abolition of grand narratives, which are the stories that create the foundations and ideological machinations of language capable of imposing themselves to local and particular narrations, are now tossed about in the wind. In the air of the contemporary era, one's story ought to be heard. It might be impossible to think of a relationship that will last for a long time, into one's old age, for it would entail listening and retelling stories over and over despite the clichéd entrance they would appear in the future. There will come a time when all the stories have been heard and the excitement for new ones might not be alluring anymore. How does one preserve a marriage such as to be able to sustain this kind of friendship? How does one sustain a lasting conversation of couples that recounts and remembers stories as though they are fresh from the experience of each other? That would be close to insanity. If there such a thing as this perceivably insane experience, the closest association is the term love. Einstein spoke of madness as doing the same things over and over and expecting another result. The experience of the past cannot be revived, nor can they be changed; they are only told and received afresh to the person who is in love. For that person, every experience, whether cliché or passé, is always new - the details become alive: the way the quintessential lover tells it, beloved's lip movement, speaking eyes, and fascinating gestures.

The point of Mignon McLaughlin comes to place: "a successful marriage requires falling in love many times, always with the same person." The success comes in a linear fashion, that is, it stems out from the times one loves the same beloved over and over, or falling in love again and again. It is a never-ending response. Deeper into this prospect of success, couples must have dreamt of things throughout their married life. From the start, dreams are a lot helpful in terms of giving hope amid the obstacles of the married life. This study then takes into account the crucial factor of dreaming, put forward by a theological assertion from Pope Francis as hinged in his speech and Post-Synodal Apostolic Exhortation on Love in the Family, Amoris Laetitia (2015). To quote Pope Francis in his meeting with Families in the Mall of Asia Arena in the Philippines on Friday, January 16, 2015, at length: 
the womb for 9 months. They dream of how they will be. It isn't possible to have a family without such dreams. When you lose this capacity to dream you lose the capacity to love, the capacity to love is lost. I recommend that at night when you examine your consciences, ask yourself if you dreamed of the future of your sons and daughters. Did you dream of your husband or wife? Did you dream today of your parents, your grandparents who carried forward the family to me? It is so important to dream and especially to dream in the family. Please don't lose the ability to dream in this way. How many solutions are found to family problems if we take time to reflect if we think of a husband or wife, and we dream about the good qualities they have. Don't ever lose the memory of when you were boyfriend or girlfriend. That is very important.

However, doing this for more than two decades might be a lot unthinkable than what it seems. Dreams may have already evaporated at such extent. Every passing day is a struggle of reality. The situation might be unlikely: "What happened to the myth of 'happy ever after'? It never matched reality" (McCarthy \& McCarthy, 2006). How can this relationship of boyfriend or girlfriend develop as a way of passing this dreaming ecstasy throughout its realization in the married life?

Hence, our question is an enduring question, considering for instance that it has already been asked before in the 1980s (Schlesinger, 1982; 2009). Throughout the development of marriage in the years that pass, what are the things that must be done and that one should have done? This is not, however, to make a formula out of the whole married state, but to emancipate things from the hindrance of non-growth in such long-term domain.

A review of the literature suggests different vantage points. One can read the endurance of lasting marriage through the significance of religion (Mackey \& O'Brien, 2008). For taking into account the sacredness of the union, religiosity plays an important role in marriages and addition to it is benevolent love (Jeffries, 2006). One can also look at it in the perspective of the conflictmanagement styles of spouses (Mackey, et. al., 2000a) or manners of adaptation (Mackey \& O'Brien, 1999). Another could be the perspective of sex (Ard, 2010) and the additional variable of being affected by prison reentry (2013). One can also see marriage in terms of strength and satisfaction (Wolcott, 1999), the latter of which can be focused on same-sex or heterosexual couples (Mackey, et. al., 2004), more particularly on psychological intimacy (Mackey, et.al., 2000b). Then there are the studies of lasting marriages in context. A study on lasting marriages was done in Israel (Sharlin, 1996), in Chile (Roizblatt, et. al, 1999), and some ethnic variability in African American marriages and families (Marks, et.al., 2006).

What is distinct in this study is (1) its highlighting of Judith Wallerstein's and Sandra Blakeslee's Nine Developmental Tasks of Marriage (1995) in their examination of lasting marriages without dismissing the guidelines set by others (LaBauve, 1997) in (2) applying it to Catholic couples in the Philippines with (3) the addition of the element of dreaming. The quaint book is a vital source in the study of these marriages. The authors' enduring evaluations match the nature of our question. Hence we ask whether Wallerstein's and Blakeslee's Nine Developmental Tasks of Marriage is still relevant today in the experience of lasting marriages of Catholic couples in the Philippines.

\section{Methodology}

\subsection{Method}

In measuring the effectiveness of Wallerstein's and Blakeslee's Nine Developmental Tasks of Marriage, the nature of the study is not only applying a theoretical framework in real life but evaluating such theory through praxis, or more particularly, attesting the theory through real-life experiences. Hence, the method of the case study will directly concern the answer of the spouses themselves through qualitative research. They will be given questionnaires which will measure to some extent the thesis of the tasks. The research to be conducted will delve on the themes of their marriage, their love, and their capacity to dream even within the state of marriage itself. The interdisciplinary nature of the study arises from the fact that the nine tasks of marriages as fitting for guidance counseling fits well with a Catholic component in Pope Francis' theological assertions in Amoris Laetitia and the significance of dreaming. 


\subsection{Questionnaire}

The questionnaire is divided into two parts: the demographic questionnaire and the research questionnaire proper. In between these inquiries, the developmental tasks of marriage will be explained in brief to be used as a guide for the couples. Both of them will be given the questions, respecting their perspectives on the matter. The questions will be derived from the proper knowledge concerning the tasks.

\subsubsection{Demographic Questionnaire}

This questionnaire serves as a piece of survey information for the study. There are 8 questions for the couples. The first being the inquiry of identity: who is your spouse or "you are married to whom?". The second question brings to light the extent of their marriage: "how long have you been married?" which makes them recall and aware of the long time that they are together. The third question is about beginnings: "when did you get married?", which determines the exact date of marriage. Following that is "what is your current age?", which is not only for survey data purposes but also in determining the age gap of the two. More particular in these statistics regarding age is the fifth question: "What was your age when you married?". The sixth question concerns proles: "Did you have children?", which is followed by a conditional: "If yes, how many?". And the last one concerns marriage experience: "How many times have you been married?"

All of the questions in the demographic form are relevant to determining the status of the marriage partners. They are suitably prepared for research purposes. The form of the questionnaire is a modified version of Alexander S. Gnilka's "A Study of the Development of Long-Term Marriages Lasting 25 Years or More" (2007), as his unpublished dissertation. In this research, there were two revisions. The first is that the question on who is the partner is added, to identify which one is the partner of whom. Second, three questions are deleted, which are the following "What is your gender?", "What is your race or ethnicity?", and "In which state were you married?". The gender question is not applicable since the Catholic form of marriage requires two heterosexual persons while the previous questionnaire contains the possibility of same-sex marriage. 'Race' also is deleted given that the participants of this study are sure to be Filipinos. And the question of state also is deleted because the context is not the USA but only locally in the Philippines.

\subsubsection{Research Questionnaire Proper}

Again, modifying Gnilka's study, the research questionnaire proper is now not suited as an Interview Protocol, since the questions will just be given as handouts or survey forms. That way, they can better think over their answers. From the study's two parts composing of 10 questions, we have altered it into 1 part composing only of 6 questions. Because the answers are written, they are given only one instruction and that is to use separate sheets of paper to answer the questions briefly.

The first one is the same grand tour question: "What has it been like being married for all these years?" with the note "(Brief)". This provides the overview sentiment, idea, or background of their marriage. The second and third question delves further into the tasks, which are given to them and are discussed with descriptions beforehand to be reviewed. The questions rank the tasks being utilized the most or least in their marriage, letting us know which are the most valued and less valued throughout their marriage. The questions 2 and 3 are: "Now that all tasks have been discussed, explain which tasks have been utilized the most in your marriage? (Top 3)" and "Which tasks have been utilized the least in your marriage? (Least 3 )." These questions will serve as the real deal in evaluating the tasks, coming from their own experiences of marriage. The fourth question is a critical one. "Are there possible new tasks that you can identify and share that have not been discussed?" followed by the conditional statements: "If no, leave the question blank. If there are, what are they?". This will find what is missing in the tasks and how they can be improved. It has been 12 years since Gnilka's study, so there may have already been new points that are not found from the nine discussed. All the questions above come from the previous interview protocol 
questionnaire. The last two questions are the researchers' addition and will function as the thematic insertion of our research questions on marriage that concerns love and dreams.

Following their experiences over the years as a couple, the fifth question seeks to extract from these a personal point of view: "How do you define love at this point?". It is rationally opined that no abstract reality can better explain this than their own lives shared together. The last question is about dreaming. Before the question, the same text of Pope Francis' message is shown to them, followed by asking "How important is dreaming in your married life?". This will evaluate how they have concretely lived Pope Francis' view and how the value of dreaming can better make sense of its enduring capacity throughout the marital bond.

\subsubsection{Participants}

The target participants are living heterosexual couples solemnized by the Catholic Church. They are married for 25 years married or more. There are only 3 couples in this research which sums up six persons following from Fusch and Ness (2015). They are given two months at most to answer the questions in their own convenience. For discussion purposes, each partner is labeled $b$ (b1...b6). The odd numbers are for husbands and the even numbers are for wives. The complete profile and rest of the respondents' verbatim answers are archived for safekeeping whenever requested through ethical procedures.

\section{Theoretical Framework: The Developmental Tasks of Marriage}

\subsection{Separation from the family of origin}

This task is the initial real-life attempt at living one's life independently from the ties of one's origin, the family. It is an act of breaking away, a separation which looks forward to one's standing on life to live life as one's own. This task, as dictum dictates, defines the struggle of beginnings. It will brave emotional and psychological hindrances in order for one to grow. It is a necessary step towards maturity. The passage to adult life begins in this separation. After which, the couple will now begin to live as one and would have to make decisions of their own together. The life that they vow to live together will now start after one has truly broken the emotional and psychological dependency from their family of origin.

\subsection{Building togetherness, intimacy, and autonomy}

This task evokes the planning and the solidified decisions the couple must envision on how they can work with the marriage for the rest of their lives. The couple projects the kind of fidelity that they want, which can help them go on in life together. Here, the concept of the self as an "I" in marriage - one's self-interest, one's likes and dislikes as priority over the other, and so on - now ceases to be and evolves into the kind of mentality which identifies in the form of "we": "what do we want together', 'how can we cope with everything that matters for us in consensus', and so on. This task rests on the scale of balance, that is, on weighing priorities and needs for the good as an act of togetherness.

\subsection{Maintain privacy while becoming a parent}

In this task, the couple has to find equilibrium between themselves as spouses and their relationship to their child(ren). It is not leaving the child(ren) but just finding the privacy of their own so that they might not lose the special relationship that they share with themselves. It is, in short, finding the balance between their partner and their child. Although they both comprise a family, the relationship with each one varies and must be maintained. 


\subsection{Confront and master crises of life}

This task corresponds to the way most people label our times today: we are living in hard times. And the crisis is not only global or local but also is particular: in the family, in relationships, and in the ordinary intricacies of married life. There are more definitions to determine the crises of married life and nothing is more relatable than the problems everyone is facing. The crises have in their angles different converging points, whether they exist outside - the workplace, third parties - or just in the internal eradication of a point in one's married life where ennui is slowly taking place. The problems in this task can either be short or long term. They also can be traceable or not, the latter being a discovery after some serious confrontations. This task then concerns how the couple acknowledges, understands, and solves their problems.

\subsection{Create a safe haven to allow for conflict}

There would be times when disagreements will settle in, whether the couple likes it or not. This is normal. So this task is essentially to create a space for conflicts to emerge in a healthy way. They should devise ways on how to cope up with heated arguments that must never become a prelude to breaking up like petty teenager fights. They have to be mature in solving arguments while not resorting to ending the marriage, and this entails prioritizing the marriage itself than their own comfort zones.

\subsection{Establish and maintain a worthwhile sexual relationship}

The task of establishing and maintaining the intimacy of marriage in sex is not just a privilege but an essential property. But more than just the practice and issue of sex, this task is to have a sense of a healthy intimate lifestyle, an idea of closeness which is defined by tenderness and understanding each other.

\subsection{Keep a sense of humor and shared interests}

In this task it is important to keep communication - and this means in any form - intact. Verbal or non-verbal communication, contacts, and the like should pervade in this task. It is then imperative to have a connection not devoid of humor and jokes. The couple must have activities that they share an interest with. It may be in the form of hobbies, exercising together, preferences, and a joint experience of leisure that each of the partners enjoys.

\subsection{Provide comfort and support to each other}

This task rests on the idea that they are not a couple for nothing: they have each other and that should give each other enough comfort and support. They are not to deal with problems alone but together, as partners, in everything. When one is down, the other should be there to support, nourish, and nurture. A tender provision is necessary in such times, providing for example assistance, empathy, reassurance, and inspiration. In short, this task is to be there when the other needs presence.

\subsection{Keep in mind why and how you originally fell in love}

This is the task of the marriage where the same imagery of the Greek god Janus is portrayed. It is the idea that in marriage, one should keep a kind of vision which deals with the past and the present and how the latter should become more aware of the former. The couple then should keep in mind why and how they fell in love. This task is not only here because it is the last in the tally, but it deserves to be placed in higher importance than the rest.

This task is where our theme of loving and dreaming in marriage enters. Pope Francis' words resonate in this task, which is to keep in mind the things that are important when the couple is still 
in the stage of their boyfriend-girlfriend relationship. However, rather than clinging more to the past, the reason and manner of loving should rather inspire the couple on the enduring presence of love in their relationship along with the future element of dreaming.

\section{Results}

\subsection{Demographics}

\section{B.1 (Husband)}

(1) You are married to whom?

(2) How long have you been married?

B.2

(3) When did you get married?

34 YEARS

(4) What is your current age?

JULY 18, 1981

(5) What was your age when you married?

64

(6) Did you have children? YES If yes how many? 6

(7) How many times have you been married? ONCE

B.2 (Wife)

(1) You are married to whom?

(2) How long have you been married? 34 YEARS

(3) When did you get married? JULY 18, 1981

(4) What is your current age? 61

(5) What was your age when you married? 24

(6) Did you have children? YES If yes how many? 6

(7) How many times have you been married? ONCE

B.3 (Husband)

(1) You are married to whom? B.4

(2) How long have you been married? 37 YEARS

(3) When did you get married? JULY 24, 1982

(4) What is your current age?

(5) What was your age when you married? 22

(6) Did you have children? YES If yes how many? 5

(7) How many times have you been married? ONCE

\section{B.4 (Wife)}

(1) You are married to whom?

(2) How long have you been married?

\section{B.3}

(3) When did you get married?

37 YEARS

(4) What is your current age?

JULY 10, 1982

(5) What was your age when you married?

(6) Did you have children? YES If yes how many? 5

(7) How many times have you been married?

B.5 (Husband)

(1) You are married to whom?

(2) How long have you been married?

(3) When did you get married?

59

22

(4) What is your current age?

(5) What was your age when you married?

(6) Did you have children? YES If yes how many? 4

(7) How many times have you been married? ONCE

B.6 (Wife)

(1) You are married to whom?

\section{B.5}

(2) How long have you been married?

31 YEARS

(3) When did you get married?

AUGUST 14, 1987

(4) What is your current age?

52

(5) What was your age when you married?

(6) Did you have children?

YES

21

(7) How many times have you been married? ONCE

31 YEARS

AUGUST 14, 1987 


\subsection{Significant Responses}

1. What has it been like being married for all these years? (Brief)

- Very happy and contented (b.1)

- Fulfilling, contented, happy \& challenging (b.2)

- Being a married couple is a lifetime commitment of serving each other 'til the end of time no matter what. (b.3)

- My married life has been always like an everyday challenge. (b.4)

- Married life is wonderful. It is enjoyable because it gives me joy and sacrifices. It gives me a chance to be a partner in building a strong family. A strong family makes a strong society. (b.5-6)

2. Now that all tasks have been discussed, explain which tasks have been utilized the most in your marriage? (Top 3)

- 2 - Building togetherness, intimacy, and autonomy (b.1, b.2)

- 3-Maintain privacy while becoming a parent (b.4)

- 4 - Confront and master crisis in life (b.4, b.5, b.6)

- 5 - Create a safe haven to allow for conflict (b.2, b.3)

- 6 - Establish and maintain a worthwhile sexual relationship

- $(b .1, b .5, b .6)$

- $7-$ Keep a sense of humor and shared interests (b.1, b.5, b.6)

- 8 - Provide comfort and support to each other (b.2)

- 9 - Keep in mind why and how you originally fell in love (b.4)

3. Which tasks have been utilized the least in your marriage? (Least 3)

- 1 - Separation from the family of origin (b.4)

- 3 - Maintain privacy while becoming a parent (b.1, b.2)

- 5 - Create a safe haven to allow for conflict (b.4, b.5, b.6)

- 6-Establish and maintain a worthwhile sexual relationship (b.2)

- 7 -Keep a sense of humor and shared interests (b.2, b.3)

- 8 - Provide comfort and support to each other $(b .1, b .4)$

- 9 - Keep in mind why and how you originally fell in love (b.1, b.5, b.6)

4. Are there possible new tasks that you can identify and share that have not been discussed?

If no, leave the question blank. If there are, what are they?

- Always Christ-centered and prayerful (for) each other (b.1)

- We as husband and wife make sure that our family will be Christ-centered. We allow ourselves to attend renewal seminars like CFC and we encourage our children to attend also the CFC family ministries like KFC, YFC, and SFC. And my husband serves as a lay minister, and me as part of our PPC. And one of our children as a parish youth leader. (b.2)

5. How do you define love at this point?

- Love is humility, to forgive and forget, understanding, patient, persevering, loyalty, and honest. (b.1)

- Love is giving, understanding each other's flaws, patience, supporting my partners' works and plans. (b.2)

- Love is the inner force which impels of performing well to the one loved. It is also about giving, sharing, and understanding each other and above all, that "love" should be anchored with the love of God. (b.3)

- At this point in time, love for me is a God-given gift being wrapped with a wrapper of eternity. So it's real and genuine. It will never fade no matter what 'til death. (b.4)

- Love is giving one's self unconditionally to your loved one, no ifs, no buts. (b.5, b.6)

6. How important is dreaming in your married life?

- It gives me courage, patience, perseverance, strong in feelings to fulfill those dreams. 
(It) challenges (me) to face the reality of being a family man. (b.1)

- It is important to dream and make some plans for our marriage, my family and especially to build a home full of joy, happiness, and peace. And I dream and pray that each of us will have the strength, good health, and be the instrument of God's love that we can share to the members of the family, to the community and in our workplace. (b.2)

- Yes! Dreaming in our married life is so important because dreaming is just like planning for a better married life in the future. (A) father in the family is considered the strong foundation while the task of the mother is only to support the weakest length of her husband in order to build the ever stronger family ties. The respectful and well-trained children in the family are somehow the everlasting fruits that will give nourishment someday. (b.3)

- I see the importance of dreaming in my married life and as I look at it, anything and everything would happen and be realized and it just started in my dream. From then on, I aim to achieve and attain it. I must never stop dreaming of/for my family. However, I must (then) have something to do for a dream to come true. I must exert effort for the realization of it for I know that God will do the rest. (b.4)

\section{Discussion and Analysis: Marrying, Loving, and Dreaming}

\subsection{Marrying: the contentment within time}

In the heart of the document, the Church - in spite of its imperfections and weaknesses - is a "family of families" (Pope Francis, Amoris Laetitia, henceforth: AL). Sacred Scriptures attest to this, that the Bible "is full of families, births, love stories and family crises (AL, 8)." And love, even though it struggles through its imperfection, does not mean that it is untrue or unreal but is real though "limited" and "unearthly" (AL, 113).

In the book Marriage that Lasts, it is clear why God is the God of Love and at the same time the God of Romance (Ricucci \& Ricucci, 2006). God isn't just interested in love but He is love (1 John 4:16). And this takes also the inclusion of romantic love between a husband and a wife. Hence, Romance Is Biblical. While the word romance is not extant in the Bible, the Sacred Scripture offers several strongly stirring examples of passionate love between a man and a woman. The Old Testament, for example, speaks of the emotional, redemptive love of Boaz for Ruth (Ruth $2: 8-16 ; 3: 8-13$ ) and of Jacob's passion for Rachel (Genesis 29:20). The entire book of "the Song of Solomon is devoted to the magnificent and wondrous love relationship between a man and a woman. And the New Testament warns husbands and wives against physical separation, except briefly for spiritual reasons" (Ricucci \& Ricucci, 2006, p. 116) (see also 1 Corinthians 7:5). The letters of Paul also speak of husbands "nourishing" and "cherishing" their wives (Ephesians 5:29). These romantic affections seen in the Word of God can then be translated in marriages also.

The biblical examples mentioned above are important to understand the romance behind the divinely fated act of love because reality is not always that proportionate to previous expectations. In the US, "studies over the past 10 years have confirmed that couples who divorce will be most likely to do so after about seven years of marriage" (Lyster, 2007, p. 12). Ironic as it may when seven in the book of Revelation means perfection, couples past the seventh year point are now overcome of the problems of the married state. After the honeymoon stage for the first five years, things start to become trivial and this has always been a serious problem for couples.

Looking at the responses of the couples who have endured 25 years or more together, one can surmise that marriage achieves its triumph of contentment in its totality. While one spouse says that he very happy and contented (b.1), his partner adds other things with that happiness and contentment - there is the presence of challenge (b.2). But more to that challenge is fulfillment: it is "fulfilling". Therein lies the testament of a lasting marriage: "Being a married couple is a lifetime commitment of serving each other 'til the end of time no matter what (b.3)." 'No matter what' here means what his spouse has to say in the reality of their marriage: "My married life has been always like an everyday challenge (b.4)." The last couple, who probably shared their thoughts and have 
come up with one answer for the both of them, well caps the point: "Married life is wonderful. It is enjoyable because it gives me joy and sacrifices. It gives me a chance to be a partner in building a strong family. A strong family makes a strong society (b.5-6)." Every family that follows the heart of the Church's teaching makes up a society of believers who are one with the passion of love in history. It becomes a marriage that lasts through love.

In the Developmental Tasks of Marriage, the diversity of responses is a testament that most of the tasks have been used and are utilized most in their marriage. All are utilized most except one, that is, the separation from the family origin. The Filipino way of marrying surely regards highly of the family that separation is not really a matter of importance. The family dynamics ironically does not separate but grows closer. There are frequent visitations and get together with relatives. In the Philippines, clan reunions are a commonplace. The top 3 from their answers explain the challenge and triumph of marriage. With three signatories equally, confronting and mastering crises in life (b.4, b.5, b.6), establishing and maintaining a worthwhile sexual relationship (b.1, b.5, b.6), and keeping a sense of humor and shared interests (b.1, b.5, b.6) are mainly used and lived. These three seem to be paramount for a lasting marriage. Even in the midst of adversities and real crises in life, it is already acknowledged that Filipinos are a happy people because we never run out of our sense of humor.

In the least utilized tasks, number 5 and 9 got the highest score. Creating a safe haven to allow for conflict is least utilized (b.4, b.5, b.6), probably because, in a debatable claim, there is a non-confrontational trait the Filipino culture possesses, although this might just be a hasty generalization. Keeping in mind why and how one originally fell in love is also least utilized (b.1, b.5, b.6). This is understandable given that they might be focused more on living love than thinking about it. And this is explained further in their answers to question 5. For them, generally, love is not a past idea one has to revisit always, but a way of life that evolves and grows.

In the twists and turns of life, there is still in marriage a kind of contentment where only those who have endured the tests of time can witness. It is a life beyond life, a realm unique only for those who find its challenges an area for growth together. As Amoris Laetitia says, "there is no need to lay upon two limited persons the tremendous burden of having to reproduce perfectly the union existing between Christ and his Church, for marriage as a sign entails 'a dynamic process..., one which advances gradually with the progressive integration of the gifts of God' (AL, 122)."

\subsection{Loving: the fruit of imperfections}

In the book Lasting Marriages, Men and Women Growing Together, the authors pointed that "in adopting a holistic perspective, we assumed that no single theory or independent variable offered a good enough explanation for understanding attractions that gave birth to the process of falling in love (Mackey \& O'Brien, 1995, p. 2)." True enough, falling in love is a contingent moment. It does not happen calculably or scientifically, although the science pertaining to its behavior may induce certain psychological hints.

But how did the couples define love at the point of their marriage after 25 years or more? One can notice the outstanding virtues of the first couple when they said: "Love is humility, to forgive and forget, understanding, patient, persevering, loyalty, and honest (b.1). It is giving, understanding each other's flaws, patience, supporting my partners' works and plans (b.2)." In all its vicissitudes, love is a partnership of virtue where one sustains the other. Two virtues are noticeable, which are, patience and forgiveness.

In the words of St. Paul to the Corinthians in the Hymn of Love, the first definition which is equated is patience: Love, before it is kind, before it is not jealous, before it rejoices with the truth, is patient (makrothymei) at first. Pope Francis explained that this is not merely the endurance of things because that one is already mentioned in the hymn. Love as patience connects to the Greek translation of the Old Testament as "slow to anger" (Ex 34:6; Num 14:18). This reflects God's patience as a sign of his power. It does not sacrifice one's dignity to be mistreated. Love as patience therefore already encapsulates what the other things of the first couple said. When love is patient, it understands the other and it presupposes humility. When love is patient, it perseveres and in its slowness to anger, does not commit acts of disloyalty and dishonesty born from bad and 
hasty decisions. Patience is giving and is hence supportive of the other. The reason why the first definition of love is patient is that God too is patient: meaning, that it is a supra-human virtue. St. Augustine affirms this when he says that "patience is the virtue of the angels; for us here on earth, prudence will do." And isn't prudence the ultimate judge we have of ourselves to make us realize that the best way for reconciliation and love to work is to understand the other to the point of forgiving his/her flaws? In the book I Don't Want a Divorce, "Forgiveness is the intellectual, emotional, and spiritual process of completely releasing all your resentments toward someone for the harm that person has done (Clarke \& Clarke, 2009, p. 139)." It has the character of the immediate conversion of the heart in the name of metanoia. Forgiveness is a threefold self-decision from the mind, the heart, and the soul which eradicates the hurt as it becomes open to being forgotten.

The second couple has a more abstract way of defining it. "Love is the inner force which impels of performing well to the one loved. It is also about giving, sharing, and understanding each other and above all, that 'love' should be anchored with the love of God (b.3)". The wife defines it thus: "At this point in time, love for me is a God-given gift being wrapped with a wrapper of eternity. So it's real and genuine. It will never fade no matter what 'til death (b.4)." In explaining why keeping in mind why and how they originally fell in love as the most utilized task in their marriage, she said: "I have a concrete faith in the Lord and no human being can fathom it. I greatly believe in the sacrament of matrimony. I want to preserve it till my end. That is the main reason why I survive in the midst of struggle, for I claim that it is God who has written a fabulous love story between me and my spouse." It is a love story indeed which God, the best love-story writer, has uniquely written. And the plot of the story moves precisely in its inner force stirring the characters to continue. It has the mark of eternity; it endures until death. Over the years, the mark of true love is a testament of its eternal character: there is God guiding the marriage and because it comes from a higher source, it is real and emits a kind of genuineness where one recognizes the authenticity of its Being.

The third couple in their unified answer says that "love is giving one's self unconditionally to your loved one, no ifs, no buts (b.5, b.6)." Isn't this the love that is Christ-like? For the third couple, this is the kind of love that sustained them in their marriage. Love is the unconditional self-giving which does not strictly abide in economic exchange, nor in a business transaction. If one will think of it as a wager, then it would lose its meaning.

Marriage is a relationship that expresses the perfection of love (Orsy, 1988, p. 18). But this relationship goes with imperfections as well. It is a "mixture of enjoyment and struggles, tensions and repose, pain and relief, satisfactions and longings, annoyances and pleasures (AL, 126)." In its variety, love's meaning enriches further and every experience becomes an essential contingency for its continual existence. That is why every point of the trial is not an endpoint; it reveals that "each crisis has a lesson to teach us; we need to learn how to listen for it with the ear of the heart (AL, 232)."

In the heart of marriage, there lies a deeper spirituality which enkindles in the couple a sense of perspective where they can continue living together. Not only is this spirituality a sign of hope but it is also a sign of strength. Love, when seen as a way of life, when seen as the inner force which keeps the couple together, when it is given with the self as it tries to be unconditional as possible, becomes a fruit even after having experienced so many imperfections. The more imperfect it is realized, the more it grows ever more to strive to be perfect in a constant state of perfection. "No family drops down from heaven perfectly formed; families need constantly to grow and mature in the ability to love ... All of us are called to keep striving towards something greater than ourselves and our families, and every family must feel this constant impulse. Let us make this journey as families, let us keep walking together. (...) May we never lose heart because of our limitations, or ever stop seeking that fullness of love and communion which God holds out before us (AL, 325)." This striving towards something greater is an impulse needed for dreaming in marriage.

\subsection{Dreaming: looking beyond love}

In the light of what Pope Francis has said, which we will repeat here, it is already established how dreaming can be an essential element of marriage. 
It is important to dream in the family. All mothers and fathers dream of their sons and daughters in the womb for 9 months. They dream of how they will be. It isn't possible to have a family without such dreams. When you lose this capacity to dream you lose the capacity to love, the capacity to love is lost. I recommend that at night when you examine your consciences, ask yourself if you dreamed of the future of your sons and daughters. Did you dream of your husband or wife? Did you dream today of your parents, your grandparents who carried forward the family to me? It is so important to dream and especially to dream in the family. Please don't lose the ability to dream in this way. How many solutions are found to family problems if we take time to reflect if we think of a husband or wife, and we dream about the good qualities they have. Don't ever lose the memory of when you were boyfriend or girlfriend. That is very important.

In fact, his statement and explanation might already be enough that the third couple did not answer it. The Holy Father's words were sufficient and perhaps already are the spoken words the couple must have uttered too. And today, more and more people have to acquaint themselves of new forms of loving in the manner of dreaming because lives nowadays are expanding. Dreaming here is not a passive mentality where the foremost interpretation is characteristic only of non-action. Dreaming is to think more and to live more of the life one is endowed with. It takes its cue from what Pope Francis calls the "transformation of love" because "Longer life spans now mean that close and exclusive relationships must last for four, five or even six decades; consequently, the initial decision has to be frequently renewed (AL, 163)." It is a kind of eternal vow that reevaluates ones promises again and again (cf. Kahambing, 2014a; 2014b).

This transformation of love is important because, in that longevity of life, the recurrent question is: what do you do when someone you love wants to change? It is hard, given that dreaming is supposed to be a past and future pact tied together. It is a move for connecting anyone's past dream to be realized in a future event in life. It resembles a general plan, for the wife, the children, and the family at large as they pass through time. Dreams always go for the better. Dreaming as a transformation of love in the long winding path of life must be a progressive series of thinking, feeling, and acting for the greater goal.

For the husbands' point of views, this is evident. One says, "It [dreaming] gives me courage, patience, perseverance, strong in feelings to fulfill those dreams. (It) challenges (me) to face the reality of being a family man (b.1)." Like St. Joseph, the husband of Mary, he also must have felt to dream and think big for the family. Being a husband is no joke. It requires a lot of patience, perseverance, and strength of emotions. It is then a challenge of every husband who has gone a long journey of married life. But with dreaming, things become bearable because is its meaning is tied to the future. It is no wonder the second husband says that "Yes! Dreaming in our married life is so important because dreaming is just like planning for a better married life in the future. (A) father in the family is considered the strong foundation while the task of the mother is only to support the weakest length of her husband in order to build the ever stronger family ties. The respectful and well-trained children in the family are somehow the everlasting fruits that will give nourishment someday (b.3)." Dreaming then not only is a essential function in the duration of the marriage but a fruitful one. It caters the future through the nourishment of its children as fruits. Amoris Laetitia says of the parents' duty for their children: "What is most important is the ability lovingly to help them grow in freedom, maturity, overall discipline and real autonomy" (AL 260)."

The wives who answered the question are much more in the trajectory of affection and the goodness dreaming brings as a light in the family. "It is important to dream and make some plans for our marriage, my family and especially to build a home full of joy, happiness, and peace. And I dream and pray that each of us will have the strength, good health, and be the instrument of God's love that we can share to the members of the family, to the community and in our workplace (b.2)." For a mother, it is paramount to build a home that not only has joy but full of joy, with happiness and peace. Truly, the mother is the light of the family because she thinks not just for herself but for all, even in the "workplace" and the community at large.

The wife in the second couple states the purposiveness of action in dreaming. "I see the importance of dreaming in my married life and as I look at it, anything and everything would happen and be realized and it just started in my dream. From then on, I aim to achieve and attain it. I must never stop dreaming of/for my family. However, I must (then) have something to do for a dream to 
come true. I must exert effort for the realization of it for I know that God will do the rest (b.4)." Dreaming needs effort, the constant realization of its importance, and persistent action, in the hope of letting God do the rest. It will never be complete to be realized that one can just dream and fulfill it always - one needs God for it to come true. For there are things which are beyond our control. It requires then a kind of vision where God is there.

Looking as God would have looked, that is to look always "beyond appearances (AL, 168)," this is dreaming for the better. "A pregnant woman can participate in God's plan by dreaming of her child (AL, 169)." This kind of looking does not stop at imperfections. It succeeds. It strives forward for a better realization and action of things. And one needs a mature perspective to realize this. One needs maturity to realistically accept one's imperfect partner; that one's cherished dreams sometimes, though wished and prayed for, cannot come true. And yet one needs to reaffirm once again the choice of that "yes" in the life they promised and dreamed to live. In this sense, love can be "renewed, deepened, and inwardly strengthened (AL, 238)."

The dream may not come true, but it is a source of strength when it does not because by then, love reaffirms itself along with the choice that constitutes it.

\section{Recapitulation / Conclusion}

In recapitulating our discussion with the enduring question in mind whether Judith Wallerstein's and Sandra Blakeslee's Nine Developmental Tasks of Marriage is still effective today, with the answers and comments of the couples, the rejoinder is an affirmative one. Some have explained the tasks and related it to their lives: what they have done and what they mean in their own experiences. The tasks are testaments of their lives. Most of the tasks are utilized either in the top three or at least three. This means that they generally are reflective of the marriages in the case study. Two couples have nothing more to add for the tasks, making them sufficient to explain the reality of their married life.

But for a Catholic couple, one can easily spot the secularity of the tasks. It was a civil procedure in the area of the humanities, and yet one couple made it clear that there is still something that is worth mentioning in marriage apart from such tasks. The husband in the first couple added that their marriage is "always Christ-centered and prayerful (for) each other (b.1)." The wife backs this when she said that "we as husband and wife make sure that our family will be Christ-centered. We allow ourselves to attend renewal seminars like [Couples For Christ] CFC and we encourage our children to attend also the CFC family ministries like KFC [Kids For Christ], YFC [Youth For Christ], and SFC [Singles For Christ]. And my husband serves as a lay minister, and me as part of our PPC [Parish Pastoral Council]. And one of our children as a parish youth leader (b.2)." This is not an ideal family in an absolute sense, but with the help and mercy of God, this is a family which is precious in the eyes of God, in the service of His people.

The family then is not a hindrance for the apostolate of the Church. If anything, serving the Church has a unitive factor. Pope Francis says that "those who have deep spiritual aspirations should not feel that the family detracts from their growth in the life of the Spirit, but rather see it as a path which the Lord is using to lead them to the heights of mystical union (AL, 316)." Every moment in marriage is a participation in the experiences of our Lord. These so-called "moments of joy, relaxation, celebration, and even sexuality can be experienced as a sharing in the full life of the resurrection (AL, 317)." It renews itself and time and lasts forever.

Finally, "all family life is a 'shepherding' in mercy. Each of us, by our love and care, leaves a mark on the life of others (AL, 322)." It is a profound "spiritual experience to contemplate our loved ones with the eyes of God and to see Christ in them (AL, 323)." Marrying, loving, and dreaming these are tasks that all correspond to the grandeur of divine love for us. They are not just human experiences, but the spiritual exercise of mercy. A family who cannot show mercy is a sheep without a shepherd. Each member exists and lives through the mercy of God translated for everyone. Belonging to the Catholic tradition, the researchers hope for more Catholic couples who will live together not just for 25 years or more but for a lifetime. Such hope hinges on a promise for couples to be one, to constantly examine, and to reconcile their lives fruitfully with God, still marrying, loving, and dreaming. 


\section{References}

Ard, B. Jr., (2010). Sex in lasting marriages: A longitudinal study. The Journal of Sex Research, 13(4), $274-285$.

Clarke, D. \& Clarke, W. (2009). I Don't Want a Divorce, A 90 Day Guide to Saving your Marriage. Michigan: Revell.

Gnilka, A. (2007). A Study of the Development of Long-Term Marriages Lasting 25 Years or More. Unpublished Dissertation Presented for the Doctor of Philosophy Degree. University of Tennessee, Knoxville.

Fusch, P. and Ness, L. (2015). Are We There Yet? Data Saturation in Qualitative Reseach. The Qualitative Report, 20(9), 1408-1416.

Jeffries, V. (2006). Religiosity, Benevolent Love, and Long-lasting Marriages. Humbolt Journal of Social Relations, 30(1), 77-106.

Kahambing, J.G. (2014a). Man of the Future: the Superman in the Eternal Vow. The Thomasian Philosopher, $30(1), 190-216$.

Kahambing, J.G. (2014b). Nietzsche's Casts of Promising towards an Eternal Vow. University of Santo Tomas.

Kahambing, J.G. (2015). The Cruelty of Loving in Philia and Amicitia. The OWL, 14, 102-107.

Kahambing, J.G. \& Deguma, J. (2019). Reflecting on the Personality of Artificiality: Reading Asimov's Film Bicentennial Man through Machine Ethics. Journal of Educational and Social Research, 9(2), 17-24.

LaBauve, M. S. (1997). Covenant Marriages: A Guise for Lasting Commitment. Loy. L. Rev., 43, 421.

Lyster, M. (2007). Building a Parenting Agreement That Works, How to Put Your Kids First When You're Marriage Doesn't Last, $6^{\text {th }}$ edition. USA: Consolidated Printers INC.

Mackey, R. \& O'Brien, B. (1995). Lasting Marriages, Men and Women Growing Together. USA: Praeger.

Mackey, R. \& O'Brien, B. (1999). Adaptation in Lasting Marriages. Family in Society: The Journal of Contemporary Social Services.

Mackey, R., Diemer, M., O'Brien, B. (2000a). Conflict-management styles of spouses in lasting marriages. Psychotherapy: Theory, Research, Practice, Training, 37(2), 134-148.

Mackey, R. A., Diemer, M. A., \& O'Brien, B. A. (2000b). Psychological intimacy in the lasting relationships of heterosexual and same-gender couples. Sex Roles, 43(3-4), 201-227.

Mackey, R. A., Diemer, M. A., \& O'Brien, B. A. (2004). Relational factors in understanding satisfaction in the lasting relationships of same-sex and heterosexual couples. Journal of Homosexuality, 47(1), 111-136.

Mackey, R. \& O'brien, B. (2008). The Significance of Religion in Lasting Marriages. Journal of Religion, Spirituality \& Aging, 18(1), 35-63.

Marks, L., Nesteruk, O., Hopkins-Williams, K., Swanson, M., \& Davis, T. (2006). Stressors in African American marriages and families: A qualitative exploration. Stress, Trauma, and Crisis, 9(3-4), 203-225.

Mccarthy, B. \& Emily, J. (2006). Getting it Right This Time, How to Create a Loving and Lasting Marriage. New York: Routledge Taylor \& Francis Group.

Nettleton, S. (2009). Ten Tips for a Great Marriage According to Friedrich Nietzsche. Indo-Pacific Journal of Phenomenology, 9(2), 1-9.

Nietzsche, F. (2001). The Gay Science: With a Prelude in German Rhymes and an appendix of songs (J. Nauckhoff \& A. Del Caro, Trans.). New York: Cambridge University Press. (Originally published: 1882)

Orsy, L. (1988). Marriage in Canon Law. Wilmington Delaware: Michael Glazier.

Pope Francis (2015). Post-Synodal Apostolic Exhortation on Love in the Family, Amoris Laetitia.

Ricucci, G. \& Riccucci, B. (2006). When Marriage Meets Grace, Love that Lasts. Illinois: Crossway Books.

Roizblatt, A., Kaslow, F., Rivera, S., Fuchs, T., Conejero, C., Zacharias, A. (1999). Long-Lasting Marriages in Chile. Contemporary Family Therapy, 21(1), 113-129.

Schlesinger, B. (1982). Lasting marriages in the 1980s. Concil. Cts. Rev., 20, 43.

Schlesinger, B. (2009). Lasting and functioning marriages in the 1980's. Canadian Journal of Community Mental Health, 2(2), 45-56

Shamblen, S. R., Arnold, B. B., Mckiernan, P., Collins, D. A., \& Strader, T. N. (2013). Applying the creating lasting family connections marriage enhancement program to marriages affected by prison reentry. Family Process, 52(3), 477-498.

Sharlin, S. (1996). Long-Term successful Marriages in Israel. Contemporary Family Therapy, 18(2), $225-242$.

Wallerstein, J. \& Blakeslee, S. (1995). The Good Marriage: How and Why Love Lasts (Boston: Houghton Mifflin. Wolcott, I. (1999). Strong families and satisfying marriages: A review of the literature. Family Matters, (53), 21. 